\title{
Analysis of stiffness and fatigue resistance of cold recycled asphalt mixtures manufactured with foamed bitumen for their application to airfield pavement design
}

\author{
H. I. Lacalle-Jiménez ${ }^{\text {a, b}} \bowtie$, J. P. Edwards ${ }^{\text {a }}$, N. H. Thom ${ }^{\text {b }}$ \\ a. AECOM, Chetwynd Business Park, Chilwell, (Nottingham, UK) \\ b. NTEC, Faculty of Engineering, The University of Nottingham, University Park, (Nottingham, UK) \\ $\triangle$ helena.lacalle@aecom.com
}

Received 15 April 2016

Accepted 10 November 2016

Available on line 17 July 2017

\begin{abstract}
Cold recycled bound materials (CRBMs) provide an economic and environmental advantage for pavements since they decrease energy and raw material consumption. However, design methods for airfield pavements do not include key CRBM properties. In this paper an empirical-mechanistic method is used to study airfield pavement design with CRBM in order to develop design guidance. The aim of the paper is to obtain the inputs related to material properties needed for use in this method. For this purpose, CRBM containing reclaimed asphalt, with fly ash, cement and foamed bitumen as stabilising agents, was characterised. The methodology included indirect tensile stiffness modulus (ITSM) and indirect tensile fatigue tests (ITFT) in strain control mode. The inputs needed for a pavement design analysis with CRBM were then obtained. The results showed the importance of further study on CRBM fatigue to understand the behaviour of these mixes under cyclic loading.
\end{abstract}

KEYWORDS: Mechanical properties; Modulus of elasticity; Fatigue; Characterisation; Fly ash

Citation/Citar como: Lacalle-Jiménez, H.I.; Edwards, J.P.; Thom, N.H. (2017) Analysis of stiffness and fatigue resistance of cold recycled asphalt mixtures manufactured with foamed bitumen for their application to airfield pavement design. Mater. Construcc. 67 [327], e127 http://dx.doi.org/10.3989/mc.2017.04616

RESUMEN: Análisis del módulo de rigidez y la resistencia a fatiga de mezclas asfálticas recicladas en frio fabricadas con betún espumado para su uso en el diseño de firmes para aeropuertos. El uso de mezclas asfálticas recicladas en frío (MARF) proporciona ventajas tanto económicas como medioambientales al disminuir el consumo de energía y materias primas. Sin embargo, los métodos de diseño para firmes de aeropuertos no incluyen las propiedades de MARFs. En este artículo un método empírico-mecanístico se emplea para estudiar el diseño de firmes de aeropuertos con MARF. El objetivo es obtener los inputs relacionados con las propiedades de MARF necesarios para llevar a cabo el diseño del pavimento. Con este propósito, MARF con asfalto reciclado, ceniza volante, cemento y betún espumado ha sido caracterizado. La metodología incluye ensayo de tracción indirecta para la obtención del módulo de rigidez y ensayo de fatiga con tracción indirecta en modo de deformación controlada. Los inputs necesarios han sido obtenidos y los resultados muestran la importancia de un estudio adicional del comportamiento a fatiga de MARF para entender su comportamiento bajo cargas cíclicas.

PALABRAS CLAVE: Propiedades mecánicas; Módulo elástico; Fatiga; Caracterización; Ceniza volante

ORCID ID: H. I. Lacalle-Jiménez (http://orcid.org/0000-0002-0126-7626); J.P. Edwards (http://orcid.org/0000-00032498-1168); N.H. Thom (http://orcid.org/0000-0003-2012-1902)

Copyright: (C) 2017 CSIC. This is an open-access article distributed under the terms of the Creative Commons Attribution License (CC BY) Spain 3.0. 


\section{INTRODUCTION}

Material that is recovered from aged asphalt pavements is known as RAP (Reclaimed Asphalt Pavement) $(1,2)$. The requirement for using RAP in new asphalt is becoming increasingly urgent (3) because of the economic and environmental benefits (3), reducing demand on finite resources, generation of waste materials and embodied energy (4).

Cold recycling of asphalt is a proven technique that reduces energy consumption (5-7). This reduction is largely achieved by avoiding aggregate drying (8) and mixing the material at ambient temperature instead of $170^{\circ} \mathrm{C}-185^{\circ} \mathrm{C}$, as required for hot mix asphalt (HMA) (9). The use of bituminous stabilising agents produces a flexible layer with superior fatigue performance to those with purely cementitious binders (10). This study looks at foamed asphalt with cement, material which is classified in the UK as a cold recycled bound material $(\mathrm{CRBM})(8,11)$.

Foamed bitumen is produced by injecting air and water droplets under high pressure (e.g. 5 bar) into hot $\left(160-180^{\circ} \mathrm{C}\right)$ liquid bitumen, resulting in the formation of foam (12). The volume of bitumen increases while viscosity considerably reduces (13). Typically foam bitumen is added to the mixture at between $3 \%$ and $5 \%$ by weight of aggregate; however, when the bitumen content of the recycled material is high, this can be reduced to $2-3 \%(2,13,14)$.

Early life CRBM mechanical properties change over time (15). This phenomenon, during which the cohesion between the binder and the aggregates increases as the mixture loses water, is known as curing $(16,17)$. No standard curing procedure has been established for CRBM; however, from previous research, it has been demonstrated that curing specimens fully wrapped at $20^{\circ} \mathrm{C}$ for 28 days is an appropriately conservative practice (16, 18 ); therefore, this curing procedure was chosen for this study.

Despite the increasingly common use of CRBMs in roads $(11,19)$, the specifications for the use of these materials in airfields are underdeveloped (8) and there is no guidance to ensure that pavement design with these materials is trustworthy (20-22). Design guides for airfield pavements such as FAArfield (23), BAA (24) or Design and Maintenance Guide 27 (DMG27) (25) do not readily allow the introduction of new material properties (20), making it difficult for authorities and practitioners to use these materials on airfield pavements. A new design approach is therefore required (22). In Figure 1 a harmonised approach for analytical pavement design of pavements using CRBM is proposed (22).

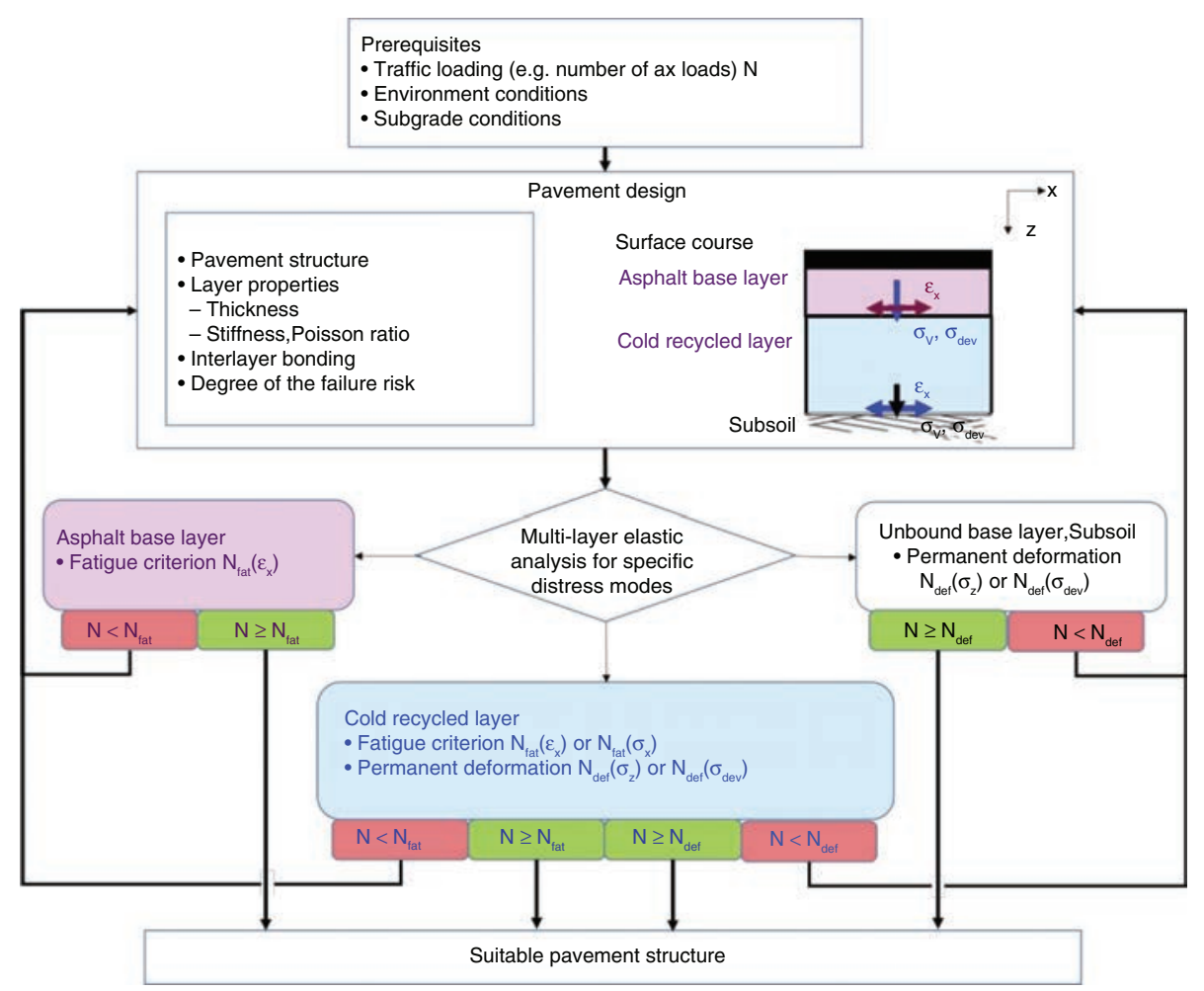

FIGURE 1. Analytical design principle for pavements with cold recycled layer (22). 


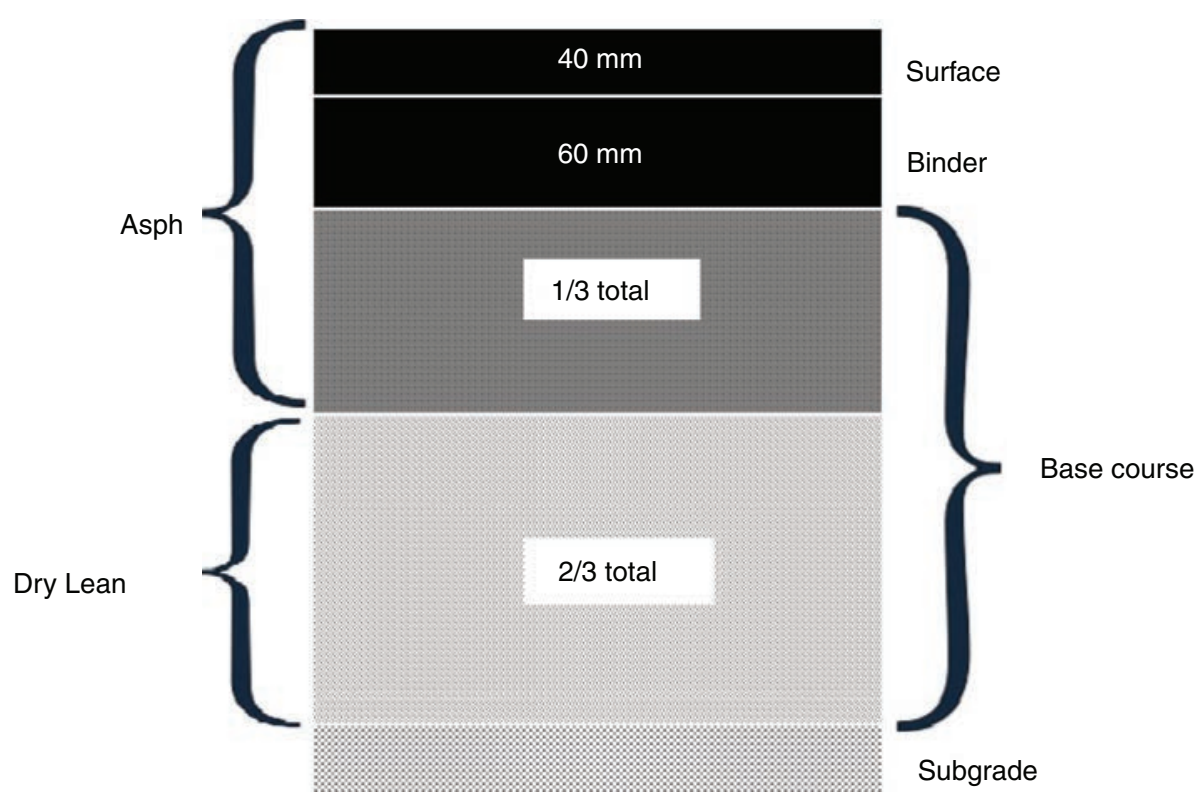

FIGURE 2. Airfield flexible pavement structure.

In this investigation Kenlayer, an empiricalmechanistic software package, was selected to undertake the multilayer-elastic analysis. This software allows analysis which can incorporate CRBM behaviour (26). It was decided to use a mechanistic design method because of the lack of the necessary performance data to undertake an empirical analysis $(21 ; 22)$. Furthermore a mechanistic method provides a theoretically sound approach as it relates the stresses, strains and deflections within a pavement structure with the loads and material properties.

The structure of airfield pavements comprises surface, binder and base courses laid on a foundation as shown in Figure 2, for new build and full rehabilitation designs $(24 ; 25)$. The surface and binder courses have typical thicknesses of 40 and $60 \mathrm{~mm}$ respectively; the base course thickness is designed as a function of traffic, subgrade conditions and desired design life (26).

According to the BAA approach the base thickness calculated is then divided into $1 / 3^{\text {rd }}$ asphalt and $2 / 3^{\text {rd }}$ dry lean concrete (24), while DMG27 requires a minimum of $120 \mathrm{~mm}$ of asphalt base to avoid reflective cracking for high traffic scenarios (25).

To carry out a pavement analysis with Kenlayer (or any other multi-layer linear elastic program), material mechanical properties need to be defined, such as stiffness, Poisson's ratio and failure criteria; these parameters therefore have to be determined for CRBM.

The material stiffness can be obtained from conventional indirect tensile stiffness modulus (ITSM) tests (27). Poisson's ratio has a relatively small effect on the pavement response (26); thus a typical value of 0.3 has been adopted here for CRBM (28). The failure criteria can be adjusted by modifying cracking and permanent deformation algorithms (26). Fatigue cracking is a common distress that affects pavement service life (29).

The failure criterion for permanent deformation is expressed by equation [1]:

$$
N_{d}=f_{1}\left(\varepsilon_{c}\right)^{-f_{2}}
$$

where $\mathrm{N}_{\mathrm{d}}$ is the allowable number of load repetitions to limit permanent deformation, $\varepsilon_{\mathrm{c}}$ is the compressive strain at the top of the subgrade, and $\mathrm{f}_{1}$ and $\mathrm{f}_{2}$ are coefficients determined from road tests or field performance (26). The compressive strain at the top of the subgrade is used as a failure criterion as the permanent deformation is considered to be caused by subgrade weakness rather than by the overlying layers (26). Taking this into account, for this research $f_{1}$ and $f_{2}$ were selected as $1.365 \times 10^{-9}$ and 4.477 respectively, these values being taken from the Asphalt Institute analytical design procedure $(26 ; 30)$.

The failure criterion for fatigue cracking is expressed by equation [2]:.

$$
N_{f}=f_{3}\left(\varepsilon_{t}\right)^{-f_{4}}\left(E_{1}\right)^{-f_{5}}
$$

where $\mathrm{N}_{\mathrm{f}}$ is the allowable number of load repetitions to prevent fatigue cracking, $\varepsilon_{t}$ is the tensile strain at the bottom of the asphalt layer, $\mathrm{E}_{1}$ is the 
elastic modulus of the asphalt layer and $\mathrm{f}_{3}, \mathrm{f}_{4}$ and $\mathrm{f}_{5}$ are coefficients determined from laboratory fatigue tests, with $\mathrm{f}_{3}$ modified to correlate with field performance observations (26).

A key aim of this paper was to evaluate at a laboratory level the parameters needed to perform a pavement analysis with Kenlayer incorporating CRBM with foamed bitumen layers, namely stiffness and fatigue coefficients, $\mathrm{f}_{3}, \mathrm{f}_{4}$ and $\mathrm{f}_{5}$.

\section{MATERIALS AND METHODS}

To obtain the inputs needed for Kenlayer mentioned in the introduction, a laboratory program was established. The materials used were specified fully in previous work (20) and are summarised in the next section.

\subsection{Materials}

For CRBM mixture manufacture, RAP, fly ash, cement and foamed bitumen were used with the mix design shown in Table 1. Fly ash was added as the RAP contained less fines than the specification demands. More information about the mix design optimization can be found in the authors' previous works $(20 ; 31)$.

The binder contents in the RAP and in the final mixture were calculated in accordance with BS 598-102 (32). Binder was recovered in accordance with BS EN 12697-3 (33) for characterisation. The recovered bitumen and the bitumen used for foaming were characterised in terms of softening point in accordance with BS EN 1427-2007 (34) and penetration grade in accordance with BS EN 1426-2007 (35). The results are shown in Table 2.

TABLE 1. CRBM mix design

\begin{tabular}{lc}
\hline \multicolumn{1}{c}{ Ingredient } & Proportion by mass (\%) \\
\hline 0-10mm RAP & 43.5 \\
10-20 mm RAP & 39.1 \\
Fly ash & 6.3 \\
Cement & 1.6 \\
Foamed bitumen & 3 \\
Total water content & 6.5 \\
\hline
\end{tabular}

TABLE 2. Bitumen characterisation

\begin{tabular}{lccc}
\hline \multicolumn{1}{c}{ Bitumen } & $\begin{array}{c}\text { Binder } \\
\text { content }(\mathbf{\%})\end{array}$ & $\begin{array}{c}\text { Penetration } \\
\left(\mathbf{2 5 ^ { \circ }} \mathbf{1 / 1 0} \mathbf{~ m m}\right)\end{array}$ & $\begin{array}{c}\text { Softening } \\
\text { point }\left({ }^{\circ} \mathbf{C}\right)\end{array}$ \\
\hline $\mathbf{1 0 0 / 1 5 0}$ & NA & 107 & 44.2 \\
RAP 0-10 $\mathbf{~ m m}$ & 7.2 & 30 & 58.6 \\
RAP 10-20 $\mathbf{~ m m}$ & 4.4 & 32 & 55.0 \\
$\begin{array}{l}\text { Recovered from } \\
\text { mixture }\end{array}$ & 7.5 & 46 & 52.4 \\
\hline
\end{tabular}

A Wirtgen WLB 10 mobile foaming plant, with the settings established in Table 3 , and a gyratory compactor were used for specimen manufacture. Specimens were double wrapped in cling film and cured for 28 days at $20^{\circ} \mathrm{C}$.

\subsection{Methodology}

The testing methodology comprised:

- Determination of indirect tensile stiffness modulus (ITSM) to BS EN 12697-26:2004 Annex C (36)

- Indirect Tensile Fatigue Tests (ITFT) in strain control mode to BS EN 12697-24:2012 Annex E (37)

\subsubsection{ITSM}

Asphalt material stiffness relates to its load spreading ability and temperature susceptibility, parameters used to assess pavement structural condition. In a structural asphalt layer, high stiffness indicates good load-spreading ability.

In determining ITSM the rise-time, which is the time taken for the applied load to increase from the initial contact load to its maximum value, was selected as $124 \mathrm{~ms} .10$ conditioning pulses were applied to set the load needed to obtain a peak horizontal deformation of $5 \mu \mathrm{m}$. To calculate the stiffness modulus 5 pulses were applied across two perpendicular diameters (36).

As stated before, the stiffness value is a material property required to undertake analysis with Kenlayer and it was measured on 37 specimens at 10,20 and $30^{\circ} \mathrm{C}$.

\subsubsection{ITFT in strain control mode}

This test was developed at the University of Nottingham (38) and monitors the stiffness variation for a specified repeated strain value and the number of cycles until failure occurs. These parameters were needed to determine the fatigue coefficients in equation [2]. This is a relatively simple test and suitable for cylindrical specimens; therefore, the manufacture of test specimens was straight-forward, saving materials and using the same compaction

TABLE 3. Foaming conditions

\begin{tabular}{lc}
\hline Water Pressure & $4 \mathrm{bar}$ \\
Air pressure & $5 \mathrm{bar}$ \\
Bitumen type & $100 / 150$ \\
Bitumen temperature & $170^{\circ} \mathrm{C}$ \\
Water addition & $1 \%$ \\
\hline
\end{tabular}


method as in the author's previous research, gyratory compaction. This also avoided the need to cut specimens from a slab, a process that can affect CRBM behaviour.

The strains selected for the ITFT were between 150 and $300 \mu \varepsilon$ (39) and the loading frequency was 2 $\mathrm{Hz}$. The test was performed at $20^{\circ} \mathrm{C}$ on 14 specimens and the failure criterion used was the conventional target of $50 \%$ reduction of stiffness value (40).

\section{ANALYSIS OF RESULTS AND DISCUSSION}

\subsection{Stiffness}

The stiffness results presented in Figure 3 show low temperature susceptibility of CRBM mixes when compared to HMA (20). This is likely to be due to the action of cement within the mixture. Regarding the stiffness value used for design (at $20^{\circ} \mathrm{C}$ ), $3500 \mathrm{MPa}$ is comparable to the values of HMA assumed in airfield base layers, for example DBM50 for which stiffness values range between $2400 \mathrm{MPa}$ and $5000 \mathrm{MPa}$ (41). It would therefore appear that CRBM with foamed bitumen has appropriate stiffness modulus for airfield pavement design.

\subsection{ITFT in strain control mode}

Table 4 shows the results from the ITFT in strain control mode for CRBM.

To obtain the coefficients, the difference between the $\mathrm{N}_{\mathrm{f}}$ obtained in the laboratory and the $\mathrm{N}_{\mathrm{f}}$ calculated using equation [2] was minimised by optimising the values required for $f_{3}, f_{4}$ and $f_{5}$. The fatigue curves obtained from laboratory tests and from calculations are presented in Figure 4.

Maggiore's data (38), shown in Table 5, were also used for analysing the adequacy of this fatigue test method, and the values of $\mathrm{f}_{3}, \mathrm{f}_{4}$ and $\mathrm{f}_{5}$ compared to those for HMA calculated by the Asphalt Institute and Shell $(26 ; 30)$. HMA results and CRBM fatigue coefficients are presented in Table 6.

It is noted that the values calculated using Maggiore's HMA data and the values proposed by Shell are comparable. Thus it seems likely that the ITFT in strain control mode is a suitable test for fatigue coefficient calculation.

TABLE 4. Experimental data from strain control fatigue tests for CRBM

\begin{tabular}{lcc}
\hline \multicolumn{1}{c}{$\mathbf{N}_{\mathbf{f}}$} & $\boldsymbol{\varepsilon}_{\mathrm{t}}$ & $\mathbf{E}_{\mathbf{1}}(\mathbf{M P a})$ \\
\hline 184279 & 0.00015 & 3426 \\
202363 & 0.00015 & 3081 \\
165563 & 0.00018 & 2219 \\
78554 & 0.00018 & 2330 \\
123526 & 0.0002 & 2343 \\
64123 & 0.0002 & 1660 \\
88723 & 0.0002 & 2895 \\
65933 & 0.00022 & 1996 \\
90173 & 0.00025 & 1711 \\
36413 & 0.00025 & 2179 \\
82223 & 0.00027 & 1390 \\
59043 & 0.00027 & 1343 \\
15183 & 0.0003 & 1432 \\
21673 & 0.0003 & 1646 \\
\hline
\end{tabular}

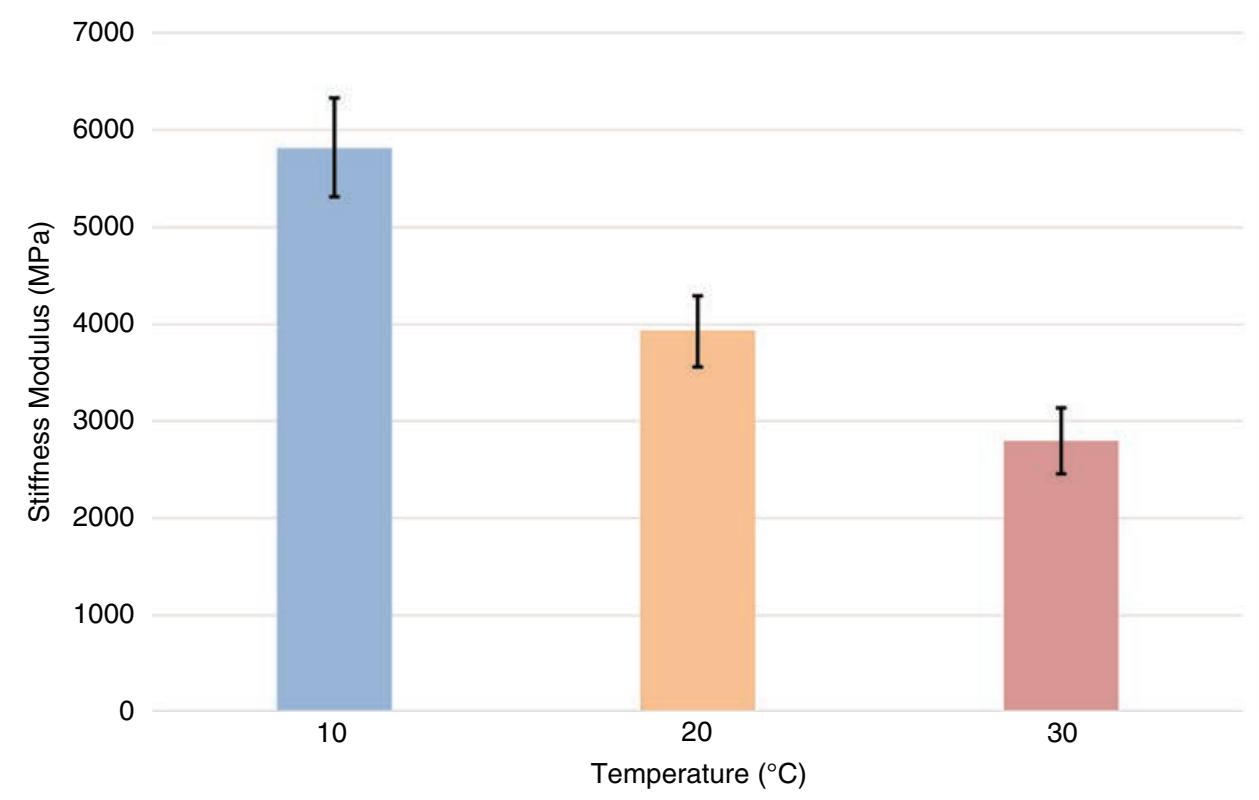

FIGURE 3. CRBM stiffness modulus. 


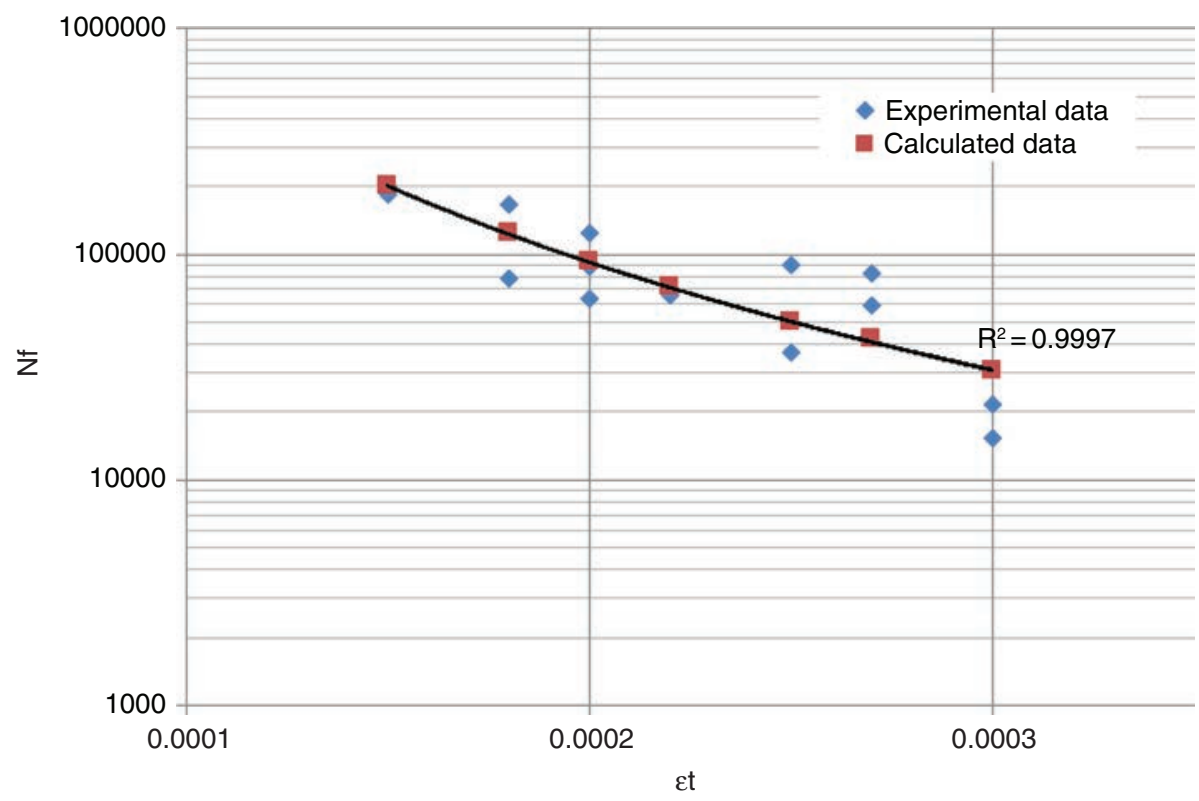

FIgURE 4. CRBM fatigue law calculation.

TABLE 5. Experimental data from strain control fatigue tests for HMA

\begin{tabular}{lcc}
\hline \multicolumn{1}{c}{$\mathbf{N}_{\mathbf{f}}$} & $\boldsymbol{\varepsilon}_{\mathrm{t}}$ & $\mathbf{E}_{\mathbf{1}}(\mathbf{M P a})$ \\
\hline 149243 & 0.000125 & 10900 \\
126500 & 0.000135 & 10329 \\
88923 & 0.000145 & 11081 \\
42613 & 0.000155 & 10231 \\
49383 & 0.000165 & 10220 \\
22393 & 0.000175 & 10582 \\
30963 & 0.000185 & 9828 \\
18683 & 0.0002 & 9928 \\
17773 & 0.00022 & 9245 \\
\hline
\end{tabular}

TABLE 6. Fatigue coefficients

\begin{tabular}{lccc}
\hline & f3 & f4 & f5 \\
\hline Calculated HMA & 0,074 & 4.842 & 3.109 \\
Shell factors & 0.0685 & 5.671 & 2.363 \\
The Asphalt institute factors & 0.0796 & 3.291 & 0.854 \\
Calculated CRMB & $7.61 \cdot 10^{-6}$ & 2.826 & 0.110 \\
\hline
\end{tabular}

Previous researchers report various values for these coefficients, with the typical range of values for $\mathrm{f}_{4}$ being between 3 and 6 (42); however, $\mathrm{f}_{3}$ varies by several orders of magnitude, and these points relate to values obtained for HMA.

With the new coefficients obtained in Table 6, the fatigue law for CRBM can be expressed as in equation [3].

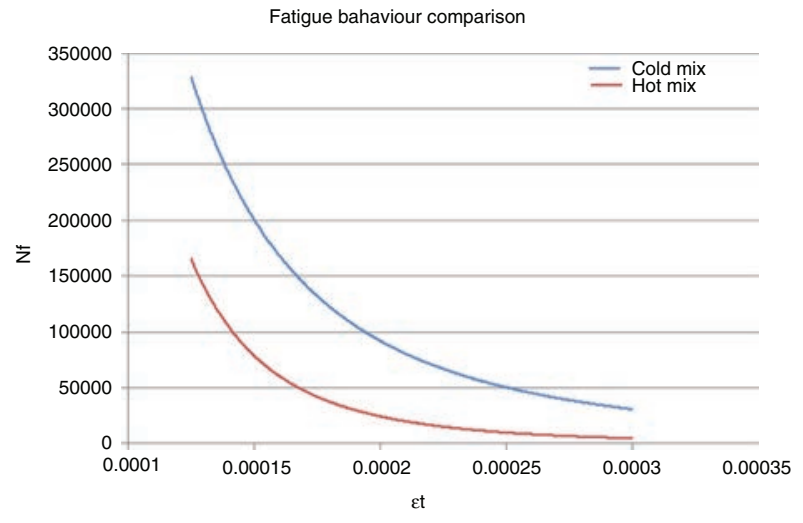

FIGURE 5. Fatigue laws comparison.

$$
N_{f}=7.61 \cdot 10^{-6}\left(\varepsilon_{t}\right)^{-2.826}\left(E_{1}\right)^{-0.11}
$$

The fatigue curves from Maggiore's data and the CRBM mix are compared in Figure 5. This comparison highlights the difference in behaviour between HMA and CRBM. It should be noted that at the same strain, CRBM has a greater life. However, the fact that CRBM stiffness is lower than that of HMA has to be taken into account; thus, when HMA reaches $50 \%$ of its initial stiffness it is deemed to have failed but the stiffness is still greater than the initial stiffness of CRBM. This highlights the necessity for further study on failure criteria.

The fundamental material input variables for CRBM assessed with the Kenlayer model have been identified as stiffness and fatigue with permanent 
deformation being dependent on the subgrade. These variables are summarised in Table 7.

It is also interesting to study the material behaviour in terms of stress evolution during testing to analyse if the modes of failure of the two materials are comparable. In Figure 6 it can be appreciated that the stress evolution is different for HMA and CRBM mixes. HMA has a near-constant stress at the beginning and then it falls relatively rapidly. For CRBM the stress starts reducing from the beginning, but at a moderate slope. This highlights the importance of studying the mode of failure for CRBM, since it does not appear to be comparable with HMA.

TABLE 7. Kenlayer inputs

\begin{tabular}{lcc}
\hline \multicolumn{1}{c}{ Input } & Value \\
\hline Poisson's Ratio & & 0.3 \\
Stiffness Modulus & $20^{\circ} \mathrm{C}$ & $3500 \mathrm{MPa}$ \\
& $\mathrm{f}_{3}$ & $7.61 \cdot 10^{-6}$ \\
Fatigue factors & $\mathrm{f}_{4}$ & 2.826 \\
& $\mathrm{f}_{5}$ & 0.110 \\
\hline
\end{tabular}

\section{CONCLUSIONS}

In this paper, the fundamental CRBM input variables for undertaking a pavement design analysis with Kenlayer have been identified as stiffness and fatigue life.

Laboratory determination of these inputs showed significant difference in the performance of CRBM versus HMA. In terms of stiffness, calculated values for CRBM are within specifications; therefore this material is identified as potentially appropriate for airfield pavement design. Fatigue coefficients have been established for CRBM; however, the failure criterion used in this research was the conventional target of $50 \%$ reduction of stiffness value, as generally used for HMA, and it remains to be investigated whether this failure criterion is also valid for CRBM.

Fatigue is a determining factor for understanding CRBM behaviour under cyclic loading. For this reason, further investigation is needed in order to develop fuller understanding of how CRBM performs, and how pavement design should best be progressed.
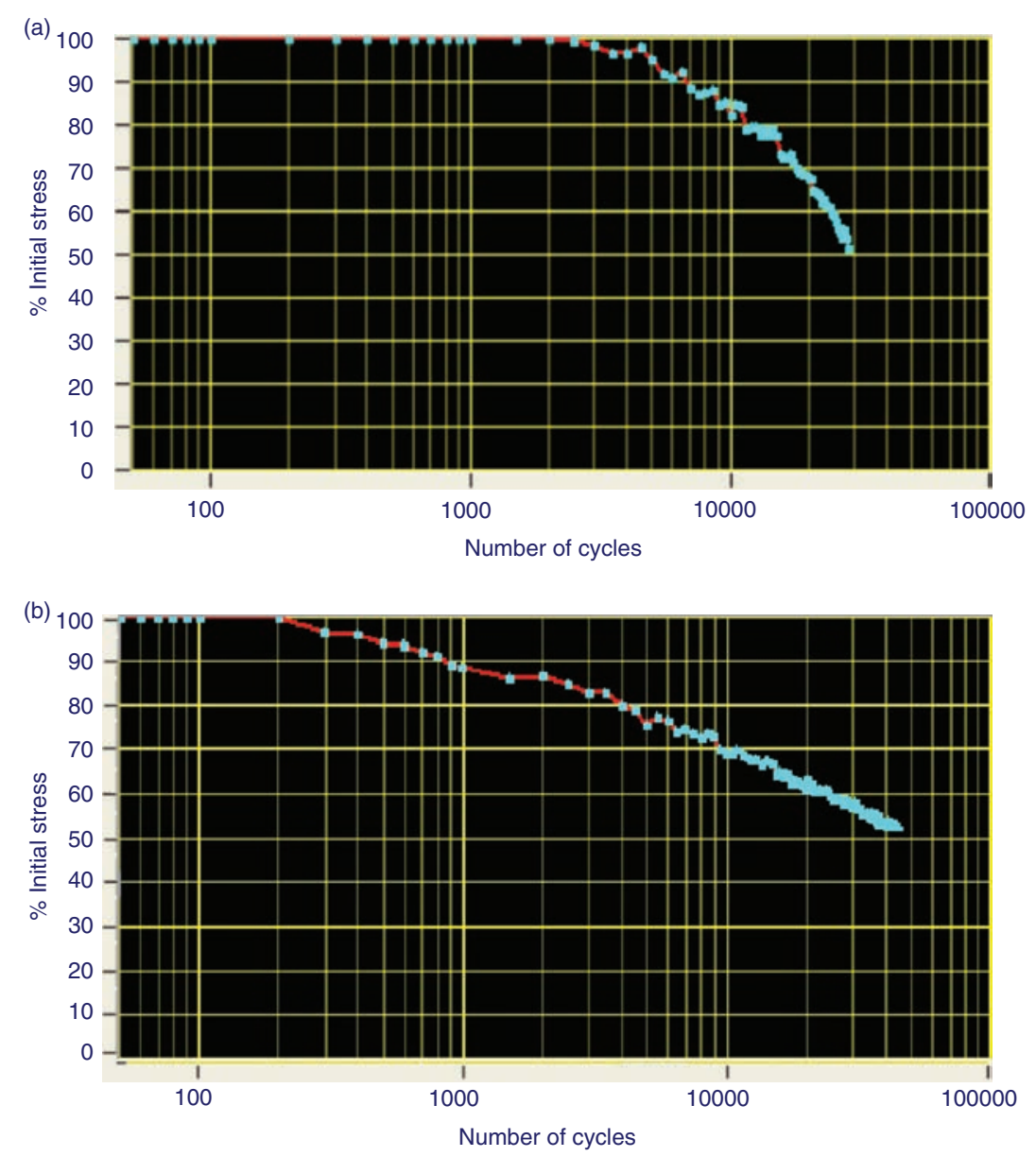

FIGURE 6. a) HMA fatigue behaviour (38) b) CRBM mix fatigue behaviour. 


\section{ACKNOWLEDGMENTS}

The research presented in this paper was carried out as part of the Marie Curie Initial Training Network (ITN) action, FP7-PEOPLE-2013-ITN (http://www.superitn.eu). The funding for the research was provided by the European Union's Seventh Framework Programme for research, technological development and demonstration under grant agreement number 607524 .

\section{REFERENCES}

1. Al-Qadi, I.L.; Elseifi, M.; Carpenter, S.H. (2007) Reclaimed asphalt pavement - A literature review. Civil engineering studies. Illinois Center for Transportation Series No. 07-001, (2007).

2. Botasso, H.G.; Cuattrocchio, A.C.; Rebollo, O.R.; Soengas, C.J. (2008) Reciclado de pavimentos asfálticos en frío. Una forma de utilizar totalmente el RAP para el mantenimiento y rehabilitación de la red caminera. Cent Investig Viales Univ Tecnológica Nac - Fac Reg La Plata, Argentina.

3. Copeland, A. (2011) Reclaimed asphalt pavement in asphalt mixtures: state of the practice. Publ No FHWA-HRT-11-021.

4. CIRIA (1999) The reclaimed and recycled construction materials handbook, London, (1999).

5. Kazmierowski, T.J.; Bradbury, A.; Cheng, S.; Raymond, C. (1992) Performance of cold in-place recycling in Ontario. Transp Res Board. [1337], 28-36.

6. Thenoux, G.; Gonzále,z Á.; Dowling, R. (2007) Energy consumption comparison for different asphalt pavements rehabilitation techniques used in Chile. Conserv Recycl Resour. 49, 325-339. https://doi.org/10.1016/j. resconrec.2006.02.005

7. Coppola, L.; Kara, P.; Lorenzi, S. (2016) Concrete manufactured with crushed asphalt as partial replacement of natural aggregates. Mater. Construcc. 66 [324], 1-7. https:// doi.org/10.3989/mc.2016.06515

8. Defence Estates (2009) Specification 050. Recycled bound materials for airfields, (2009).

9. Defence Estates (2005) Specification 012 Hot Rolled Asphalt and Macadam for Airfields, (2005).

10. Kearney, E.; Huffman, J. (1999) Full-reclamation process. Transp Res Rec. 1684 , 203-209. https://doi. org/10.3141/1684-24

11. Merrill, D.; Nunn, M.; Carswell, I. (2004) TRL report TRL611. A guide to the use and specification of cold recycled materials for the maintenance of road pavements. TRL limited, (2004).

12. Wirtgen GmbH (2012) Wirtgen cold recycling technology, Wirtgen GmnH, (2012).

13. Jitareekul, P. (2009) An investigation into cold in-place recycling of asphalt pavement. PhD Thesis, University of Nottingham, (2009).

14. Lanre, O.O. (2010) A study on the development of guidelines for the production of bitumen emulsion stabilised RAPs for roads in the tropics. PhD Thesis, The University of Nottingham. (2010)

15. Serfass, J.P.; Poirier, J.E.; Henrat, J.P.; Carbonneau, X. (2004) Influence of curing on cold mix mechanical performance. Mater Struct. 37, 365-368. https://doi.org/10.1007/ BF02481685

16. Ojum, C. (2015) The design and optimisation of cold asphalt emulsion mixtures. PhD Thesis, The University of Nottingham, (2015).

17. Jenkins, K.J. (2000) Mix design considerations for cold and half-warm bituminous mixes with emphasis on foamed bitumen. PhD Thesis, University of Stellenbosch, (2000).

18. Department for transport (2008) Manual of contract documents for highway works, Volume 1. Specification for highway works: Series 900.Road pavements. Bituminous bound materials, (2008).
19. West, R.C.; Willis, J.R. (2014) Case studies on successful utilizaion of reclaimed asphlt pavement and recycled asphalt shingles. NCAT Report 14-06.

20. Lacalle Jiménez, H.I.; Thom, N.H.; Edwards, J.P. (2016) Comparison between laboratory results for cold recycled bound materials and DBM 50 used in airfield pavements. 6th Euroasphalt Eurobitume Congr. https://doi. org/10.14311/EE.2016.120

21. Cardno, C.A. (2012) Florida uses greener cold asphalt recycling. Civ Eng.

22. Valentin, J.; Mondschein, P.; Fiedler, J.; Mollenhauer, K.; Batista, F.; Freire, A.C.(2014) Report on incorporation of cold- recycled pavement layers in empirical and mechanistic pavement design procedures, CEDR, (2014).

23. U.S. Department of transportation (2015) Federal aviation administration. . Retrieved July 4, 2016, from http://www. faa.gov/airports/engineering/design_software/

24. BAA plc Group Technical Services (1993) Aircraft pavements. Pavement design guide for heavy aircraft loading. BAA pcl group technical services, (1993).

25. Defence Estates (2011) A guide to airfield pavement design and evaluation. Design \& Maintenance Guide 27. Ministry of defence (2011).

26. Huang, Y.H. (2004) Pavement design and analysis. Pearson/ Prentice Hall, Kentucky, (2004).

27. Č́žžková, Z.; Valentin, J.; Suda, J.; Krpálek, O.; Simnofske, D.; Batista, F. (2014) Report on Durability of cold-recycled mixes : Test procedures for stiffness determination. CEDR, (2014).

28. Xu, L. (2016): Typical values of Young's elastic modulus and Poisson's ratio for pavement materials. . Retrieved from www.academia.edu

29. Moreno-Navarro, F.; Rubío Gamez, M.C.; Tomás Fortún, E.; Valor Hernández, F.; Ramírez Ródriguez, A. (2014) Evaluation of the fatigue macro-cracking behavior of crumb rubber modified bituminous mixes. Mater Construcción. 64 [315], 1-7. https://doi.org/10.3989/mc.2014.07913

30. Shook, J.F.; Finn, F.N.; Witczak, M.W.; Monismith, C.L. (1982) Thickness design of asphalt pavements - the Asphalt Institute method. Fith Int Conf Struct Des Asph pavements.

31. Lacalle Jiménez, H.I.; Tuck, J. (2015) Laboratory trials of cold recycled foamed bitumen asphalt: RAF Waddington. Int J Pavement Eng Asph Technol. 16 [1], 82-95.

32. British Standard (2003) BS 598-102: 2003 Sampling and examination of bituminous mixtures for roads and other paved areas. Part 102: Analytical test methods.

33. British Standard (2013) BS EN 12697-3:2003 Bituminous mixtures. Test methods for hot mix asphalt. Par 3: Bitumen recovery: Rotary evaporator.

34. British Standard (2007) BS EN 1427:2007Bitumen and bituminous binders. Determination of the softening point. Ring and Ball method.

35. British Standard (2006) BS EN 1426:2006 Bitumen and bituminous binders. Determination of needle penetration.

36. British Standard (2012: BS EN 12697-26: 2012 Bituminous mixtures. Test methods for hot mix asphalt. Part 26: Stiffness.

37. British Standard (2012) BS EN 12697-24:2012 Bituminous mixtures. Test methods for hot mix asphalt Part 24: Resistance to fatigue.

38. Maggiore, C. (2014) A comparison of different test and analysis methods for asphalt fatigue. PhD Thesis, The University of Nottingham, (2014).

39. Kavussi, A.; Modarres, A. (2010) A model for resilient modulus determination of recycled mixes with bitumen emulsion and cement from ITS testing results. Constr Build Mater. 24, 2252-2259. https://doi.org/10.1016/j.conbuildmat.2010.04.031

40. Ghuzlan, K.A.; Carpenter, S.H. (2000) Energy-Derived, Damage-Based failure criterion for fatigue testing. Transp Res Rec. 1723, 141-149. https://doi.org/10.3141/1723-1841.

41. Widyatmoko, I. (2002) Some practical aspects of performance related testing of bituminous materials. Perform Bitum Hydraul Mater Pavements. 99-104.

42. Barenberg, E.J.; Thompson, M.R. (1992) Calibrated mechanistic structural analysis procedures for pavements. Transp Res Boa. NCHRP Project 1-26. 